\title{
Immunosenescence and nutrition: reviewing clinical evidence on pre-, pro- and synbiotics in aging
}

\author{
Renata Ramalho ${ }^{1,2,3 *}$ \\ ${ }^{1}$ Instituto Superior de Ciências da Saúde Egas Moniz [ISCSEM] - Department of Nutrition, Campus Universitário Quinta da Granja, 2829 - 511 Monte de \\ Caparica, Portugal \\ ${ }^{2}$ Centro de Investigação Interdiscipilinar Egas Moniz [CiiEM], Campus Universitário Quinta da Granja, 2829 - 511 Monte de Caparica, Portugal \\ ${ }^{3}$ Grupo de Estudos em Nutrição Aplicada [GENA] - ISCSEM, Campus Universitário Quinta da Granja, 2829 - 511 Monte de Caparica, Portugal
}

\begin{abstract}
Aging is considered a complex process, characterized by a general decline in physiological functions, as well as increased morbidity and mortality. Being old, healthy and autonomous for the daily life constitute the hallmark of successful aging. However, dependency and frailty are common to people aged 65 or older. The aging process in accompanied by altered immune responsiveness, both at the adaptive and innate levels, that are correlated to malnutrition and frailty. Immunosenescence is also a contributor for increase susceptibility to infections and to vaccination resistance in the elderly.
\end{abstract}

The impact of aging in mucosal immunity or mucosal immunosenescence has gained the interest of researchers in recent years. Mucosal immune response is impaired in elderly, probably adding a contribution to reduced vaccination efficacy and increased susceptibility to infection. The impact of aging on mucosal immunity may indicate a possible role of therapeutic modulation of mucosal immunosenescence by pre-, probiotics and synbiotics.

In this review, the author gathered the most relevant clinical evidence regarding the effect of pre-, pro- and synbiotics in innate and adaptive immune responses of people aged 65 or older. The concepts and immunological features of immunosenescence and mucosal immunosenescence were also carefully reviewed.

\section{Introduction}

World population has been aging in last decades, with profound modifications in demographics and public health [1]. In 2010, $8 \%$ of world's population was estimated to be aged 65 or older, corresponding to nearly 524 million people [1]. Triplication of this number is expected by the year 2050, with 1.5 billion people considered old [1]. Some of this dramatic change in world's demography may be explained by the considerable improvements in public health, mainly those leading to a shift in the cause of disease and mortality [2,3]. It is widely accepted that the major health threats early in $20^{\text {th }}$ century, were infectious and parasitic diseases $[4,5]$. Currently, humanity face a new paradigm in health and disease, being forced to fight against chronic diseases that drag for long periods, causing essentially morbidity and loss of life quality [6-9].

Aging is considered a complex process, characterized by a general decline in physiological functions, as well as increased morbidity and mortality $[1,9]$. The most important aspect of aging is the chronic inflammatory status, named "inflamm-ageing" [10,11] strictly associated with the deterioration of the immune function, termed "immunosenescence" [12]. Both are causes of increased susceptibility of elderly to infectious diseases, cancer, dementia, cardiovascular diseases and autoimmunity, and of a decreased response to vaccination [10, 1315]. Research in this field as captured the attention of both researchers and academics, and the role of nutrition in this has gathered more relevance in recent years [16].

In this review, main concepts of immunosenescence and its effect on metabolism were revised. Also, clinical evidence on the effects of pre- and probiotics in aging was gathered and discussed, in a perspective of achieving a successful aging.

\section{Successful aging}

Longevity is not always synonymous of many years lived with health and autonomy; in fact, successful aging is a better measure of this [17-19]. Being old, healthy and autonomous for the daily life constitute the hallmark of successful aging [17-19]. It is recognized that the aging process is always somehow accompanied by some degree of physical and metabolic deterioration; but the balance between these expected alterations and the environment and life style may be the answer to achieve a longer life with independence and well-being.

Some regions of the Earth, known as "blue zones", are considered geographic clusters of longevity [20]. The proportion of centenarians and those aged 90 or older in the total population, is consistently increased in these regions; and people not only live longer as they are active past the age of 100 years [20,21]. Examples of "blue zones" are Sardinia in Italy, Okinawa in Japan, Loma Linda in California and Nicoya Peninsula in Costa Rica [20]. The successful aging achieved in these regions may be influenced by environmental factors, such as special local soil, water, and air, a "Mediterranean" dietary pattern, and special psychologic and sociologic conditions [less stress, commensalism, mutual aid], that protects people from the general

Correspondence to: Renata Ramalho, Instituto Superior de Ciências da Saúde Egas Moniz, Campus Universitário Quinta da Granja, 2829 - 511 Monte de Caparica, Portugal, Email: rramalho@egasmoniz.edu.pt

Key words: Aging, adaptive immunity, innate immunity, immunosenescence, prebiotics, probiotics, synbiotics

Received: July 29, 2017; Accepted: August 29, 2017; Published: September 02, 2017 
decline in physiological functions and maintains independence and physical activity [22]. Studies with centenarians, considered examples of successful aging, have been promising in increasing knowledge about factors that influence senescence and in outline strategies to fight chronic diseases and dependency in older people [21,22].

\section{Immunosenescence}

The term immunosenescence was first coined by Roy Walford in 1969 [23]. At this time, autoimmunity was pointed as the core characteristic of immunosenescence. Since then, the concept has been evolving and, nowadays, immunosenescence is regarded as the state of altered immune responsiveness, both at the adaptive and innate levels, expected to arise as aging occurs [12,22,24]. From the perspective of the first line of defence, the process of aging affects both the physical and cellular barriers of the immune system [12,25,26]. It is well accepted that decrease of skin cell replacement, sweat production and overall reduction of barrier function with deterioration of epidermal immune response, occurs [25].

The effect of aging on cells of innate system has been observed in dendritic cells, neutrophils, natural killer cells, macrophages and microglial cells. This effect has been explored in translational studies that point to significant reductions on chemotaxis and phagocytosis, antigen presentation, cytotoxicity, activation of transduction signalling, and secretion of and response to cytokines [27-31]. Regarding cytokines, studies indicated that immunosenescent cells have lower secretion of interferon [particularly, INF- $\gamma$ ] and TNF- $\alpha$, and have reduced response to IL-2 [32]. In the adaptive arm of the immune system, the main effects of aging have been described as age-related decrease of the novo generation of both $\mathrm{B}$ and $\mathrm{T}$ lymphocytes [33]. This altered immune response may also be regarded as the decline of the immune response and/or the inadequate elevation of inflammation.

So, this paradoxical context, where chronic low-level inflammation is present along with immunodepression and autoimmunity, has been explained by some central theories: autoimmune, deregulation, immune deficiency, and oxidative theories [10,34,35]. Regardless of the main features explored by those theories, inflammation and oxidative stress have been drawn increasing attention [10,24]. as it has been implicated in many chronic disabling and common diseases that have a clear association with advancing aging [atherosclerosis, type 2 diabetes, osteoporosis, for example].

\section{The impact of aging on immunity}

\section{Immunosenescence and innate immunity}

As previously mentioned, neutrophils, dendritic cells, monocytes/ macrophages and natural killer cells, are the cells of the innate immune system most affected by aging.

The majority of evidence points to the lack of changes in the number of neutrophils, and to a reduction in its physiologic function, although there is still some controversy on this topic [36]. It has been demonstrated that neutrophils functions are severely compromised with age, mainly those related to chemotaxis, phagocytosis, and intracellular killing through radical production [36-40]. There is also evidence that homeostasis of these cells is altered, especially their susceptibility to spontaneous and induced apoptosis which is increased. These alterations in functionality seem to be accompanied by changes in signalling molecules traffic and in signalling of TLRs $[38,40]$.

Regarding monocytes, there is some evidence of decrease in TLR1/ TLR2-mediated cytokine production, reduction in CD16- and increase of in CD16+ cells, with age [41-43]. Number of macrophages seems to be preserved in older people, although some important functions were revealed to be reduced in healthy aging. Some of these functions are phagocytosis, chemo taxis, superoxide production, signal transduction, apoptosis, TLR expression and function, MHC II expression, and cytokine production [41-43]. On the other hand, PGE production was demonstrated to be increase by macrophages with age [41-43].

As well as for other cells of the innate immune system, dendritic cells are also affected by effects of aging process [41]. Both the plasmocytoid and myeloid phenotypes of these antigen presenting cells, of major importance in linking the innate and the adaptive arms of immune system, are compromised in the elderly [44-46]. pDC from older individuals show lower production of IFN I/III and lower capacity for antigen presentation. In addition, $\mathrm{mDC}$, display reduced TLR-mediated signalling, antigen presentation, chemo taxis and endocytosis [36,45].

Important effects of aging on NK cells have been described, both in number, function and phenotype. The absolute number of NK cells is increased with aging, accompanied by a reduction in CD56bright and increased in CD56dim [47,48]. Increased expression of CD57 by Cd56dim cells has also been reposted [47, 48]. These changes may, in part, explain the alterations observed in the phenotype and in the functionality of NK cells during aging, as well as the decrease proliferative response observed in older people. Overall cytotoxicity seems to be unchanged; but when considering the cytotoxicity to the K562 target cells per NK cell, this has been demonstrated to be reduced. Another important alteration observed in aged NK cells is on natural cytotoxicity receptors, mainly the reduction in the expression of the activating receptor NKp30 and expression of NKp46 [47-51]. This may lead to a decreased capacity of these cells to collaborate in the initiation of the adaptive immune response against virus-infected or tumour cells [47-51]. Regarding cytokine production, CD56bright cells of elderly presents increase production of INF- $\gamma$, possibly as a compensatory mechanism to maintain immunoregulation in older people, and lower production of chemokines in response to IL-2 or IL-12 [47-51].

\section{Immunosenescence and adaptive immunity}

Increased susceptibility to infection and decreased response to vaccination have been two of major concerns in older people [13]. In fact, decreased ability of the elderly to respond to new antigens and vaccinations, contribute to reduced control of infectious diseases later in life, and are a consequence of a senescent adaptive immune system [27, 52].

Impairment of humoral immunity mediated by immunosenescence is less studied than that of cellular immunity [33]. However, it is widely accepted that humoral immune response is compromised by the aging process, especially the functionality and the number of $\mathrm{B}$ cells [25]. Data on alterations in B cells point to decreased number of circulating $B$ cells, lower antibodies production, sifts in the magnitude of B cell compartments, changed of specificity repertoires and of B cell dynamics, and overall weakened humoral responses in older humans [53-55]. Both percentage and absolute number of total CD19+ B cells are reduced, and number of $B$ cells precursors in bone marrow seems to be also lower during aging process [56-58]. Regarding functionality, antibodies are less protective, and demonstrate lower ability to opsonize in vitro after vaccination, tan those from young humans [54, 59-61]. Response to influenza after vaccination and recirculating of long-lived antibody plasma cells in the bone marrow, are also reduced in elderly [58]. Interestingly, serum IgG and IgA levels of elderly and centenarians are increased, although the number of peripheral B cells 
and their ability to produce antibodies are decreased [62-64]. This paradox is also accompanied by reduction in IgM and unchanging in IgD serum levels $[53,58]$.

Immunosenescence of T cells is well studied. Evidence from animal and human studies point to reduced percentage and absolute number of circulating CD3+ T cell and of subsets CD4+ and CD8+ [65-67]. A gradual shift from naïve CD45RA+ to activated or memory CD45RO+ cells has been reported, probably explained by thymic involution and the associated differentiation into antigen-experienced memory or effector cells [68]. One important feature observed during aging, is the increased proportion of senescent $\mathrm{Cd} 8+\mathrm{CD} 28-\mathrm{T}$ cells [68]. This has been correlated with frailty and impairment of vaccination response to influenza in elderly $[15,65]$. These senescent CD8+CD28- T cells are dysfunctional and present additional defects on CD40L [CD156+] expression, leading to lower ability to help B cells to proliferate and to produce immunoglobulins [67, 69-71]. Some degree of controversy still remains when considering the effect of aging in CD4+:CD8+ ratio [72].

\section{Mucosal immunosenescence}

As previously presented, the effects of aging on both the innate and adaptive immune system seem to increase the susceptibility of older people to infections and to vaccination resistance. Recently, the effects of the aging process on mucosal immune system competence has gathered more interest from researchers and academics [73]. The concept of mucosal immunosenescence has been evolved, and regardless of some controversies there is more information about the impact of aging process on mucosal immune system [73-75]. Studies have been shown that mucosal immune response is impaired in elderly, probably adding a contribution to reduced vaccination efficacy and increased susceptibility to infection [75-77]. This impairment is observed for all the compartments of mucosal immune system, but especially in gut-associated lymphoid tissue [GALT] [77, 78].

Regarding GALT, the most relevant and interesting impairment observed in elderly is related to the composition of microbiota [79]. Recent literature supports that pathogenic bacteria are increased in GALT from elderly, whereas beneficial anaerobes [Bacteroides and Bifidobacteria] are reduced [80-83]. In fact, bacteria from the genera Fusobacteria, Propionobacteria, Clostridia, Enterobacteria, Streptococci, Staphylococci and yeasts, are demonstrated to be increased in the elderly [73, 79, 84-87]. This shift in intestinal microflora composition has been associated to increased putrefaction, inflammation, and susceptibility to infection [73, 87]. Another element of this equation is the age-associated malnutrition [84, 88, 89]. In fact, the elderly are more susceptible to malnutrition and to their deleterious effects on immunity, than young ones [88]. Malnutrition observed in older people is an important contributor to changes in intestinal microflora composition [82, 90-93]. Some functional alterations resulted from the aging process affect local dendritic cells, especially reducing the uptake of luminal antigens. M cells on Peyer's patches are also affected, presenting lower maturity [94-96]. However, no changes in the number of dendritic cells and Peyer's patches are described in elderly. Regarding secretory IgA, studies have been reported conflicting results. Other important effects in resident macrophages, such as reduction in cytokine production from and in antigen presentation capacity, have been also reported [78, 97, 98].

\section{Modulation of immune response by pre- pro- and synbiotics}

Since 1907, that Nobel laureate Élie Metchnikoff's discoveries on the hypothesis that certain bacteria may modulate the aging process resulted from the activity of putrefactive microbes producing toxic substances in the large bowel, have been gained substantial improvement [99]. The original observations of Metchnikoff that certain rural populations in Europe had exceptionally longer life, living mainly on milk fermented by lactic-acid bacteria, gave rise to the concept of "intestinal autointoxication", which was associated to some physical changes associated with old age, and that seemed to be reverted by the colonization of harmless lactic-acid bacteria and suppression of proteolytic bacteria [99-104]. During the $20^{\text {th }}$ century the interest on probiotics reached high levels, being studied for utility in several distinct conditions. Meanwhile, some disappointing results have cooled the minds of the scientific community on probiotics. In the $21^{\text {st }}$ century, it seems that probiotics are regained attention from the several stakeholders involved in the health process. Although many strains are used as probiotics, the main used in research are Lactobacillus rhamnosus, Lactobacillus reuteri, Bifidobacteria spp., certain strains of Lactobacillus casei, Lactobacillus acidophilus-group, and the yeast Saccharomyces boulardii [100].

Immunomodulatory effects of probiotics are known to be strainand dose-dependent $[102,103]$. In fact, results are somehow conflicting when attempting to gather the clinical evidence of these food products. However, anti-inflammatory activity of L. helveticus, L. rhamnosus GG, L. reuteri and Bifidobacteria spp., had been demonstrated [102]. Some mechanisms of action on immune system, claimed for probiotics are activation of macrophages, NK cells, antigen-specific cytotoxic T lymphocytes, release of anti-inflammatory cytokines, and increase IgA levels [103]. When considering the effects on microbiota, probiotics seem to be able to colonize gut mucosa, competing with pathogenic bacteria for implantation and nutrients $[82,105]$.

Regarding prebiotics, they are considered to be non-digestible fibres that affect the host's health by selectively stimulating growth and/or activity of some genera of probiotics [such as Lactobacilli spp. and Bifidobacteria spp.] [100]. These products should be resistant to the actions of stomach acids, bile salts and hydrolysing enzymes in the intestine; and be easily fermentable by the beneficial intestinal microbiota [106]. Prebiotics should also have proved beneficial effects on health of the host. Nowadays, inulin, oligofructose and galactooligossacharides are considered prebiotics meeting the FAO/WHO criteria [100].

Synbiotics are a combination of probiotics and prebiotics and represent an interesting form of nutritional modulation [102]. These food products may increase the chance of survival of probiotics in the gut, and therefore enhancing their growth and activity [100].

\section{Pre- pro- and synbiotics in aging immune system}

When considering the effects of aging in immune system, and associating the possible effects of pre-, pro- and synbiotics in modulating immune responses systemically and in local immune system, it may be expected that probiotics exert some beneficial effects for elderly [101,104,106,107]. The question is whether the mechanistic effects studied in cell cultures and animal models, effectively applies to humans, and what kind of recommendation may be done. Some evidence is available concerning randomized clinical trials [RCT] addressing this issue [108-117]. This has been gathered, and is presented in table 1 . The major problem when gathering these studies is the considerable amount of heterogeneity which difficult a metanalysis, and therefore a convincing recommendation. As it will be discussed later, this heterogeneity is mainly due to different dosages, strains, duration of treatments and formulations tested in clinical trials. 


\section{Probiotics}

All the six RCT [108-113] included in this review demonstrated some degree of positive effects in innate, adaptive and/or mucosal immunity of people aged 65 or older, with probiotics ingestion. These effects are summarized in table 1 . Enhancement of NK cell activity was demonstrated in four studies [108,109,111,112], anti-inflammatory effects in four [108-110,113], and increased tumoricidal and/or phagocytic activity in two [111,113]. Regarding effects on adaptive immune system, increased number of T cells [total CD3+ and/or CD4+ naïve and/or CD8+ naïve] was described in two studies [109,112]. In the study from Ouwehand et al. increased number of beneficial bacteria and reduction of pathogenic bacteria were observed in faeces, after six-month consumption of oat-based drink/day B. longum [110]. As demonstrated in table 1, interventions are considerable different between studies, making it difficult to compare results between them.

\section{Prebiotics}

Two RCT addressed the effect of prebiotics in immune system of elderly $[114,115]$. One tested a mixture of galacto-oligosaccharide

Table 1 Characteristics and main results of randomized controlled trials addressing the effect of pre-, pro-, and synbiotics in systemic or mucosal immune systems of older humans.

\begin{tabular}{|c|c|c|c|c|}
\hline Study / Reference & Design and Participants & Intervention & Outcomes & Results \\
\hline \multicolumn{5}{|l|}{ Probiotics } \\
\hline Dong et al., 2013 [108] & $\begin{array}{l}\text { - Randomized, placebo- } \\
\text { controlled, single-blinded } \\
\text { crossover study } \\
\text { - } 30 \text { healthy volunteers (18 } \\
\text { females), 54-74 years old. }\end{array}$ & $\begin{array}{l}\text { - } 65 \mathrm{ml} / \text { daily Yakult light ( L. casei } \text { Shirota } \\
6.5 \times 10^{9} \mathrm{CFU} / \text { bottle) twice a day for } 4 \text { weeks. } \\
\text { - Placebo: } 130 \mathrm{ml} \text { skimmed milk twice a day } \\
\text { for } 4 \text { weeks }\end{array}$ & $\begin{array}{l}\text { - Biochemical profiles } \\
\text { - Inflammatory markers } \\
\text { - Innate immunity } \\
\text { - Adaptive immunity }\end{array}$ & $\begin{array}{l}\text { - Increase in NK cell activity, reduction } \\
\text { of MFI of CD25 expression on resting } \\
\text { T cells. } \\
\text { - Trend towards an increased ratio IL- } \\
\text { 10:IL-12. }\end{array}$ \\
\hline $\begin{array}{l}\text { Moro-Garcia et al., } 2013 \\
\text { [109] }\end{array}$ & $\begin{array}{l}\text { - Multi-centre, randomized, } \\
\text { placebo-controlled, double- } \\
\text { blinded study } \\
\text { - } 47 \text { healthy volunteers ( } 40 \\
\text { females), } 65-90 \text { years-old }\end{array}$ & $\begin{array}{l}\text { - } 3 \text { capsules/day L. delbrueckii subsp } \\
\text { bulgaricus } 8481\left(3 \times 10^{7} \mathrm{CFU}\right)+S \text {. } \\
\text { thermophilus for } 6 \text { months } \\
\text { Placebo: } 3 \text { capsules/day with cornstarch for } \\
6 \text { months }\end{array}$ & $\begin{array}{l}\text { - Biochemical profiles } \\
\text { - Inflammatory markers } \\
\text { - Innate immunity } \\
\text { - Adaptive immunity }\end{array}$ & $\begin{array}{l}\text { - Increase in NK cell percentage. } \\
\text { - Increase in naïve CD4+ and naïve CD8+ } \\
\text { T cells. } \\
\text { - Decrease in IL-8. } \\
\text { - Increase in hBD-2. }\end{array}$ \\
\hline $\begin{array}{l}\text { Ouwehand et al., } 2008 \\
\text { [110] }\end{array}$ & $\begin{array}{l}\text { - Randomized, placebo- } \\
\text { controlled, double-blinded } \\
\text { study } \\
\text { - } 209 \text { elderly in nursing homes } \\
\text { (170 females), } 84.3 \pm 0.98 \\
\text { years old }\end{array}$ & $\begin{array}{l}\text { - } 1 \text { bottle oat-based drink/day B. longum } 2 \mathrm{C}+ \\
\text { B. longum } 46 \text { for } 6 \text { months } \\
\text { - Placebo: } 1 \text { bottle oat-based drink/day for } 6 \\
\text { months }\end{array}$ & $\begin{array}{l}\text { - Faecal microbiota } \\
\text { - Inflammatory markers }\end{array}$ & $\begin{array}{l}\text { - Increase in faecal levels of } B \text {. } \\
\text { adolescentis and B. catenulatum } \\
\text { - Modest decrease in IL-10. }\end{array}$ \\
\hline Gill et al., 2001[111] & $\begin{array}{l}\text { - Randomized, controlled, } \\
\text { single-blinded crossover study } \\
\text { - } 27 \text { healthy volunteers (16 } \\
\text { females), 60-84 years-old }\end{array}$ & $\begin{array}{l}\text { - Group A: } 250 \mathrm{ml} / \text { day reconstituted milk with } \\
\text { L. rhamnosus } \mathrm{HN} 001\left(5 \times 10^{9} \mathrm{CFU}\right) \text { for } 3 \\
\text { weeks } \\
\text { - Group B: } 250 \mathrm{ml} / \text { day reconstituted milk with } \\
\text { L. lactis } \mathrm{HN} 019\left(5 \times 10^{9} \mathrm{CFU}\right) \text { for } 3 \text { weeks } \\
\text { - Control: } 250 \mathrm{ml} / \text { day non-supplemented milk } \\
\text { for } 3 \text { weeks }\end{array}$ & - NK cell activity & $\begin{array}{l}\text { - Increase in } \mathrm{CD} 56+(\mathrm{NK} \text { cells) for both } \\
\text { groups A and } \mathrm{B} \\
\text { - In vitro tumoricidal activity of PBMC for } \\
\text { both groups A and B }\end{array}$ \\
\hline Gill et al., 2001 [112] & $\begin{array}{l}\text { - Randomized, controlled, } \\
\text { single-blinded crossover study } \\
\text { - } 30 \text { healthy volunteers (18 } \\
\text { females), 63-84 years-old }\end{array}$ & $\begin{array}{l}\text { - Group high-dose: } 250 \mathrm{ml} / \text { day reconstituted } \\
\text { milk with B. lactis } \mathrm{HN} 019\left(5 \times 10^{10} \mathrm{CFU}\right) \text { for } \\
2 \text { weeks } \\
\text { - Group low-dose: } 250 \mathrm{ml} / \text { day reconstituted } \\
\text { milk with B. lactis } \mathrm{HN} 019\left(5 \times 10^{9} \mathrm{CFU}\right) \text { for } \\
2 \text { weeks } \\
\text { - Control: } 250 \mathrm{ml} / \text { day non-supplemented milk } \\
\text { for } 2 \text { weeks }\end{array}$ & - Innate immunity & $\begin{array}{l}\text { - Increase in total CD3+ T cells, CD4+ T } \\
\text { cells, CD25+ T cells and CD56+ (NK } \\
\text { cells) for both high-dose and low-dose } \\
\text { groups, with no differences between } \\
\text { them. } \\
\text { - In vitro phagocytic activity of PMN and } \\
\text { MNN for both high-dose and low-dose } \\
\text { groups, with no differences between them. }\end{array}$ \\
\hline $\begin{array}{l}\text { Arunachalam et al., } 2000 \\
\text { [113] }\end{array}$ & $\begin{array}{l}\text { - Randomized, placebo- } \\
\text { controlled, double-blinded } \\
\text { study } \\
\text { - } 25 \text { healthy volunteers ( } 18 \\
\text { females), 60-83 years-old }\end{array}$ & $\begin{array}{l}\text { 180ml reconstituted milk with } B \text {. lactis } \\
\text { HN019 }\left(1.5 \times 10^{11} \mathrm{CFU}\right) \text { twice a day for } 6 \\
\text { weeks } \\
\text { Placebo: } 180 \mathrm{ml} \text { reconstituted milk twice a } \\
\text { day for } 6 \text { weeks }\end{array}$ & - Innate immunity & $\begin{array}{l}\text { - Increase in IFN- } \gamma \text { production } \\
\text { - Enhance in phagocytic capacity of PMN }\end{array}$ \\
\hline \multicolumn{5}{|l|}{ Prebiotics } \\
\hline $\begin{array}{l}\text { Vulevic et al., } 2015 \\
\text { [114] }\end{array}$ & $\begin{array}{l}\text { Randomized, placebo- } \\
\text { controlled, double-blinded } \\
\text { cross-over study } \\
\text { - } 40 \text { healthy volunteers ( } 25 \\
\text { females), } 65-80 \text { years-old }\end{array}$ & $\begin{array}{l}\text { - } 5.5 \mathrm{~g} / \text { day B-GOS (galacto-oligosaccharide } \\
\text { mixture) for } 10 \text { weeks } \\
\text { - Placebo: } 5.5 \mathrm{~g} / \text { day Maltodextrin for } 10 \text { weeks }\end{array}$ & $\begin{array}{l}\text { - Faecal microbiota } \\
\text { - Inflammatory markers } \\
\text { - Innate immunity }\end{array}$ & $\begin{array}{l}\text { - Increase in faecal number of } \\
\text { bifidobacteria and bacteroides. } \\
\text { - Increase in IL-10 and IL-8 production. } \\
\text { - Reduction in IL-1 } \beta \text { production } \\
\text { - Increase in NK cell activity. }\end{array}$ \\
\hline Bunout et al., 2002 [115] & $\begin{array}{l}\text { - Randomized, placebo- } \\
\text { controlled, double-blinded } \\
\text { study } \\
\text { - } 43 \text { healthy volunteers, } \geq 70 \text { years }\end{array}$ & $\begin{array}{l}\text { - } 6 \mathrm{~g} / \text { day } 70 \% \text { raftilose }+30 \% \text { raftiline mixture } \\
\text { for } 28 \text { weeks } \\
\text { - } 6 \mathrm{~g} / \text { day Maltodextrin for } 28 \text { weeks }\end{array}$ & $\begin{array}{l}\text { - Innate immunity } \\
\text { - Adaptive immunity }\end{array}$ & - No effect. \\
\hline \multicolumn{5}{|l|}{ Synbiotics } \\
\hline $\begin{array}{l}\text { Macfarlane et al., } 2013 \\
{[116]}\end{array}$ & $\begin{array}{l}\text { Randomized, placebo- } \\
\text { controlled, double-blinded } \\
\text { cross-over study } \\
\text { 43 volunteers ( } 22 \text { females), } \\
65-83 \text { years-old }\end{array}$ & $\begin{array}{l}\text { - } 1 \text { gelatin capsule } B \text {. longum }\left(2 \times 10^{11} \mathrm{CFU}\right)+6 \mathrm{~g} \\
\text { Synergy I (Inulin+Oligofructose) twice a day } \\
\text { for } 2 \text { weeks } \\
\text { Placebo: } 1 \text { capsule potato starch }+6 \mathrm{~g} \\
\text { Maltodextrose twice a day for } 2 \text { weeks }\end{array}$ & $\begin{array}{l}\text { - Faecal microbiota } \\
\text { - Inflammatory markers } \\
\text { - Biochemical profiles }\end{array}$ & $\begin{array}{l}\text { - Increase in number of faecal } \\
\text { bifidobacteria (Actinobacteria and } \\
\text { Firmicutes). } \\
\text { - Reduction in faecal Proteobacteria. } \\
\text { - Reduction in TNF- } \alpha \text {. }\end{array}$ \\
\hline $\begin{array}{l}\text { Ouwehand et al., } 2009 \\
\text { [117] }\end{array}$ & $\begin{array}{l}\text { - Randomized, placebo- } \\
\text { controlled, double-blinded } \\
\text { parallel study } \\
\text { - } 47 \text { volunteers ( } 35 \text { females), > } \\
65 \text { years-old }\end{array}$ & $\begin{array}{l}\text { - } 1 \text { sachet }(5-5.5 \mathrm{~g}) \text { L. acidophilus } \text { NCFM } \\
\left(2 \times 10^{9} \mathrm{CFU}\right)+\mathrm{Lactilol} \text { twice a day for } 2 \text { weeks } \\
\text { - Placebo: } 1 \text { sachet }(5 \mathrm{~g}) \text { Sucrose twice a day } \\
\text { for } 2 \text { weeks }\end{array}$ & $\begin{array}{l}\text { - Faecal microbiota } \\
\text { - Mucosal immunity } \\
\text { - SCFA production }\end{array}$ & $\begin{array}{l}\text { - Increase in number of faecal } \\
\text { Bifidobacterium } \\
\text { - Increase in spermidine levels } \\
\text { - Modest increase in PGE2 concentration } \\
\text { in faeces }\end{array}$ \\
\hline
\end{tabular}


[GOS] [114], and the other, a mixture of raftiline and raftilose [115]. The study from Bunout $e t$ al., failed to demonstrated effects of tested intervention [115], but in the study from Vulvelic et al., increased number of beneficial bacteria in faeces, anti-inflammatory action through reduction of IL-10 and IL-1 and increased NK cell activity, were demonstrated [114].

\section{Synbiotics}

Two RCT studied synbiotics in this context $[110,116]$, one testing a combination of B. longum, inulin and oligofructose [116] and the other, L. acidophilus NCFM and lactilol [117]. Both studies demonstrated increased number of beneficial bacteria in faeces [table 1]. In the study from Macfarlane et al. [116], it was also demonstrated reduction of TNF- $\alpha$ levels, and in the study from Ouwehand et al., reduction of spermidine levels [117].

\section{Conclusion}

Senescence of the immune system represents a challenge for dealing with increased prevalence of chronic diseases in an increasingly aging population. Immunosenescence affects both the innate and adaptive immunity, correlating with malnutrition and frailty, common to people aged 65 or older. In recent years, mucosal immunosenescence has gained the interest of researchers. The impact of aging on mucosal immunity, especial on microbiota, may indicate a possible role of therapeutic modulation of mucosal immunosenescence by pre-, probiotics and synbiotics. Gathering evidence on RCT addressing the effects of pre-, probiotics and synbiotics in immunosenescence outcomes in elderly, demonstrated that the evidence is scarce, with reduced number of studies and including small groups of participants. Also, the heterogeneity in designs and types of interventions is an important limitation to compare results and to perform a recommendation. Despite this limitation, it seems that pre-, probiotics and synbiotics may represent a nutritional modulation for immunosenescence. Larger, well-designed, RCT, with lower heterogeneity in interventions, are need to prove the interest of these food products in contributing to a healthy immune system through aging, and therefore an option to achieve successful aging.

\section{Acknowledgement}

The author wishes to thank Professor Luís Delgado for his valuable contribution in her training in Immunology; and to Professor Paula Pereira for her constant support and encouragement as colleague and friend.

\section{Conflict of interest}

None to declare.

\section{References}

1. Beard JR, Officer A, de Carvalho IA, Sadana R, Pot AM, et al. (2016) The World report on ageing and health: a policy framework for healthy ageing. Lancet 387: 2145-2154. [Crossref]

2. Halaweish I, Alam HB (2015) Changing demographics of the American population. Surg Clin North Am 95: 1-10. [Crossref]

3. Lunenfeld B (2008) An Aging World--demographics and challenges. Gynecol Endocrinol 24: 1-3. [Crossref]

4. Armstrong GL, Conn LA, Pinner RW (1999) Trends in infectious disease mortality in the United States during the 20th century. JAMA 281: 61-66. [Crossref]

5. Vercelli M, Lillini R, Quaglia A, Micale RT, La Maestra S, et al. (2014) Age-related mortality trends in Italy from 1901 to 2008. PLoS One 9: e114027. [Crossref]

6. Dalen JE, Alpert JS, Goldberg RJ, Weinstein RS (2014) The epidemic of the 20(th) century: coronary heart disease. Am J Med 127: 807-812. [Crossref]
7. Al-Thani MH, Sadoun E, Al-Thani AA, Khalifa SA, Sayegh S, et al. (2014) Change in the structures, dynamics and disease-related mortality rates of the population of Qatari nationals: 2007-2011. J Epidemiol Glob Health 4: 277-287. [Crossref]

8. Bauer UE, Briss PA, Goodman RA, Bowman BA (2014) Prevention of chronic disease in the 21st century: elimination of the leading preventable causes of premature death and disability in the USA. Lancet. 384: 45-52. [Crossref]

9. Hui L (2015) Aging and chronic disease as independent causative factors for death and a programmed onset for chronic disease. Archives of gerontology and geriatrics 60: 178-182.

10. Cannizzo ES, Clement CC, Sahu R, Follo C, Santambrogio L (2011) Oxidative stress, inflamm-aging and immunosenescence. J Proteomics 74: 2313-2323. [Crossref]

11. Franceschi C, Bonafè M, Valensin S, Olivieri F, De Luca M, et al. (2000) Inflammaging. An evolutionary perspective on immunosenescence. Ann N Y Acad Sci 908: 244254. [Crossref]

12. Franceschi C, Bonafe M, Valensin S (2000) Human immunosenescence: the prevailing of innate immunity, the failing of clonotypic immunity, and the filling of immunological space. Vaccine 18: 1717-1720. [Crossref]

13. Crétel E, Veen I, Pierres A, Bongrand P, Gavazzi G (2010) [Immunosenescence and infections, myth or reality?]. Med Mal Infect 40: 307-318. [Crossref]

14. Deeks SG (2011) HIV infection, inflammation, immunosenescence, and aging. Annu Rev Med 62: 141-155. [Crossref]

15. Fulop T, McElhaney J, Pawelec G, Cohen AA, Morais JA, et al. (2015) Frailty, Inflammation and Immunosenescence. Interdiscip Top Gerontol Geriatr 41: 26-40. [Crossref]

16. Szarc vel Szic K, Declerck K, VidakoviÄ $\ddagger$ M, Vanden Berghe W (2015) From inflammaging to healthy aging by dietary lifestyle choices: is epigenetics the key to personalized nutrition? Clin Epigenetics 7: 33. [Crossref]

17. Anton SD, Woods AJ, Ashizawa T, Barb D, Buford TW, et al. (2015) Successful aging Advancing the science of physical independence in older adults. Ageing Res Rev 24: 304-327. [Crossref]

18. Li CI, Lin CH, Lin WY, Liu CS, Chang CK, et al. (2014) Successful aging defined by health-related quality of life and its determinants in community-dwelling elders. $B M C$ public health 14: 1013. [Crossref]

19. Martin P, Kelly N, Kahana B, Kahana E, Willcox BJ, et al. (2015) Defining successful aging: a tangible or elusive concept? Gerontologist 55: 14-25. [Crossref]

20. Huang Y, Mark Jacquez G (2017) Identification of a Blue Zone in a Typical Chinese Longevity Region. Int. J. Environ. Res 14: 571

21. Appel LJ (2008) Dietary patterns and longevity: expanding the blue zones. Circulation 118: 214-215. [Crossref]

22. Panagiotakos DB, Chrysohoou C, Siasos G, Zisimos K, Skoumas J, et al. (2011) Sociodemographic and lifestyle statistics of oldest old people ( $>80$ years) living in ikaria island: the ikaria study. Cardiology research and practice 2011: 679187.

23. Effros RB (2005) Roy Walford and the immunologic theory of aging. Immun Ageing 2: 7. [Crossref]

24. Franceschi C, Capri M, Monti D, Giunta S, Olivieri F, et al. (2007) Inflammaging and anti-inflammaging: a systemic perspective on aging and longevity emerged from studies in humans. Mechanisms of ageing and development 128: 92-105. [Crossref]

25. Fuentes E, Fuentes M, Alarcón M, Palomo I (2017) Immune System Dysfunction in the Elderly. An Acad Bras Cienc 89: 285-299. [Crossref]

26. Shanley DP, Aw D, Manley NR, Palmer DB (2009) An evolutionary perspective on the mechanisms of immunosenescence. Trends Immunol 30: 374-381. [Crossref]

27. Coe CL, Lubach GR, Kinnard J (2012) Immune senescence in old and very old rhesus monkeys: reduced antibody response to influenza vaccination. Age (Dordrecht, Netherlands) 34: 1169-1177.

28. Della Bella S, Bierti L, Presicce P, Arienti R, Valenti M, et al. (2007) Peripheral blood dendritic cells and monocytes are differently regulated in the elderly. Clin Immunol 122: 220-228. [Crossref]

29. Faria AM, de Moraes SM, de Freitas LH, Speziali E, Soares TF, et al. (2008) Variation rhythms of lymphocyte subsets during healthy aging. Neuroimmunomodulation 15: 365-379.

30. Palacios MG, Cunnick JE, Winkler DW, Vleck CM (2007) Immunosenescence in some but not all immune components in a free-living vertebrate, the tree swallow. Proc Biol Sci 274: 951-957. [Crossref] 
31. Sebastian C, Herrero C, Serra M, Lloberas J, Blasco MA, et al. (2009) Telomere shortening and oxidative stress in aged macrophages results in impaired STAT5a phosphorylation. Journal of immunology 183: 2356-2364.

32. Wang Q, Westra J, van der Geest KS, Moser J, Bijzet J, et al. (2016) Reduced levels of cytosolic DNA sensor AIM2 are associated with impaired cytokine responses in healthy elderly. Exp Gerontol 78: 39-46. [Crossref]

33. Colonna-Romano G, Buffa S, Bulati M, Candore G, Lio D, et al. (2010) B cells compartment in centenarian offspring and old people. Current pharmaceutical design 16: 604-608.

34. Guarner V, Rubio-Ruiz ME (2015) Low-grade systemic inflammation connects aging, metabolic syndrome and cardiovascular disease. Interdiscip Top Gerontol 40: 99-106. [Crossref]

35. Weyand CM, Goronzy JJ (2016) Aging of the Immune System. Mechanisms and Therapeutic Targets. Annals of the American Thoracic Society 13: supplement422-s8. [Crossref]

36. Bueno V, Sant'Anna OA, Lord JM (2014) Ageing and myeloid-derived suppressor cells: possible involvement in immunosenescence and age-related disease. Age (Dordrecht, Netherlands) 36: 9729. [Crossref]

37. Chen MM, Palmer JL, Plackett TP, Deburghgraeve CR, Kovacs EJ (2014) Age-related differences in the neutrophil response to pulmonary pseudomonas infection. Exp Gerontol 54: 42-46. [Crossref]

38. Panda A, Arjona A, Sapey E, Bai F, Fikrig E, et al. (2009) Human innate immunosenescence: causes and consequences for immunity in old age. Trends Immunol 30: 325-333. [Crossref]

39. Sapey E, Greenwood H, Walton G, Mann E, Love A, et al. (2014) Phosphoinositide 3-kinase inhibition restores neutrophil accuracy in the elderly: toward targeted treatments for immunosenescence. Blood 123: 239-48.

40. Wessels I, Jansen J, Rink L, Uciechowski P (2010) Immunosenescence of polymorphonuclear neutrophils. ScientificWorldJournal 10: 145-160. [Crossref]

41. Linton PJ, Thoman ML (2014) Immunosenescence in monocytes, macrophages, and dendritic cells: lessons learned from the lung and heart. Immunol Lett 162: 290-297. [Crossref]

42. Rawji KS, Mishra MK, Michaels NJ, Rivest S, Stys PK, et al. (2016) Immunosenescence of microglia and macrophages: impact on the ageing central nervous system. Brain 139: 653-661. [Crossref]

43. Suchy D, Labuzek K, Buldak L, Szkudlapski D, Okopien B (2014) Comparison of chosen activation markers of human monocytes/macrophages isolated from the peripheral blood of young and elderly volunteers. Pharmacological reports : PR 66: 759-765.

44. Chougnet CA, Thacker RI, Shehata HM, Hennies CM, Lehn MA, et al. (2015) Loss of Phagocytic and Antigen Cross-Presenting Capacity in Aging Dendritic Cells Is Associated with Mitochondrial Dysfunction. J Immunol 195: 2624-2632. [Crossref]

45. Ciaramella A, Spalletta G, Bizzoni F, Salani F, Caltagirone C, et al. (2011) Effect of age on surface molecules and cytokine expression in human dendritic cells. Cellular immunology 269: 82-89.

46. Orsini G, Legitimo A, Failli A, Massei F, Biver P, et al. (2012) Enumeration of human peripheral blood dendritic cells throughout the life. International immunology 24: 347-356.

47. Campos C, Pera A, Lopez-Fernandez I, Alonso C, Tarazona R, et al. (2014) Proinflammatory status influences NK cells subsets in the elderly. Immunol Lett 162: 298-302. [Crossref]

48. Gayoso I, Sanchez-Correa B, Campos C, Alonso C, Pera A, et al. (2011) Immunosenescence of human natural killer cells. J Innate Immun 3: 337-343. [Crossref]

49. Bigley AB, Spielmann G, Agha N, O’Connor DP, Simpson RJ (2016) Dichotomous effects of latent $\mathrm{CMV}$ infection on the phenotype and functional properties of CD8+ T-cells and NK-cells. Cellular immunology 300: 26-32. [Crossref]

50. Campos C, Pera A, Sanchez-Correa B, Alonso C, Lopez-Fernandez I, et al. (2014) Effect of age and CMV on NK cell subpopulations. Exp Gerontol 54: 130-137. [Crossref]

51. Ma Y, Fang M (2013) Immunosenescence and age-related viral diseases. Sci China Life Sci 56: 399-405. [Crossref]

52. Pera A, Campos C, López N, Hassouneh F, Alonso C, et al. (2015) Immunosenescence: Implications for response to infection and vaccination in older people. Maturitas 82: 50-55. [Crossref]
53. Frasca D, Blomberg BB (2011) Aging affects human B cell responses. J Clin Immunol 31: 430-435. [Crossref]

54. Kogut I, Scholz JL, Cancro MP, Cambier JC (2012) B cell maintenance and function in aging. Semin Immunol 24: 342-349. [Crossref]

55. Tabibian-Keissar H, Hazanov L, Schiby G, Rosenthal N, Rakovsky A, et al. (2016) Aging affects B-cell antigen receptor repertoire diversity in primary and secondary lymphoid tissues. European journal of immunology 46: 480-492.

56. Allman D, Miller JP (2005) B cell development and receptor diversity during aging. Curr Opin Immunol 17: 463-467. [Crossref]

57. Scholz JL, Diaz A, Riley RL, Cancro MP, Frasca D (2013) A comparative review of aging and B cell function in mice and humans. Curr Opin Immunol 25: 504-510. [Crossref]

58. Wang C, Liu Y, Xu LT, Jackson KJ, Roskin KM, et al. (2014) Effects of aging, cytomegalovirus infection, and EBV infection on human B cell repertoires. J Immunol 192: 603-611. [Crossref]

59. Frasca D, Romero M, Diaz A, Alter-Wolf S, Ratliff M, et al. (2012) A molecular mechanism for TNF-alpha-mediated downregulation of B cell responses. $J$ Immunol 188: 279-286. [Crossref]

60. Henry CJ, Casas-Selves M, Kim J, Zaberezhnyy V, Aghili L, et al. (2015) Aging associated inflammation promotes selection for adaptive oncogenic events in B cell progenitors. The Journal of clinical investigation 125: 4666-4680. [Crossref]

61. Ratliff M, Alter S, Frasca D, Blomberg BB, Riley RL (2013) In senescence, ageassociated B cells secrete TNFalpha and inhibit survival of B-cell precursors. Aging cell 12: 303-311. [Crossref]

62. Ichihara Y, Okano M, Nishioka K, Manabe N, Ichihara N, et al. (2009) Aging exacerbates restraint stress-induced inhibition of antigen-specific antibody production in mice. Allergology international : official journal of the Japanese Society of Allergology 58: 119-124.

63. Maeda K, Mehta H, Drevets DA, Coggeshall KM (2010) IL-6 increases B-cell IgG production in a feed-forward proinflammatory mechanism to skew hematopoiesis and elevate myeloid production. Blood 115: 4699-4706. [Crossref]

64. Remarque EJ, Nijhuis EW, Hinloopen B, Nagelkerken L, van der Velde EA, et al (1996) Correlation between the antibody response to influenza vaccine and helper T cell subsets in healthy aging. Vaccine 14: 127-130.

65. Macaulay R, Akbar AN, Henson SM (2013) The role of the T cell in age-related inflammation. Age (Dordr) 35: 563-572. [Crossref]

66. Nikolich-Žugich J (2014) Aging of the T cell compartment in mice and humans: from no naive expectations to foggy memories. J Immunol 193: 2622-2629. [Crossref]

67. Zhang W, Brahmakshatriya V, Swain SL (2014) CD4 T cell defects in the aged: causes, consequences and strategies to circumvent. Exp Gerontol 54: 67-70. [Crossref]

68. Larbi A, Fulop T (2014) From "truly naive" to "exhausted senescent" T cells: when markers predict functionality. Cytometry Part A. the journal of the International Society for Analytical Cytology 85: 25-35.

69. Garg SK, Delaney C, Toubai T, Ghosh A, Reddy P, et al. (2014) Aging is associated with increased regulatory T-cell function. Aging Cell 13: 441-448. [Crossref]

70. Herndler B D, Landgraf K, Tzankov A, Jenewein B, Brunauer R, et al. (2012) The impact of aging on memory $\mathrm{T}$ cell phenotype and function in the human bone marrow. Journal of leukocyte biology 91: 197-205.

71. Totsuka T, Kanai T, Nemoto Y, Tomita T, Tsuchiya K, et al. (2008) Immunosenescent colitogenic CD4(+) T cells convert to regulatory cells and suppress colitis. European journal of immunology 38: 1275-1286.

72. Chou JP, Effros RB (2013) T cell replicative senescence in human aging. Curr Pharm Des 19: 1680-1698. [Crossref]

73. Horan MA (1993) Immunosenescence and mucosal immunity. Lancet 341: 793-794 [Crossref]

74. Barathan M, Mohamed R, Vadivelu J, Chang LY, Saeidi A, et al. (2016) Peripheral loss of CD8(+) CD161(++) TCRValpha7.2(+) mucosal-associated invariant T cells in chronic hepatitis $\mathrm{C}$ virus-infected patients. European journal of clinical investigation 46: 170-180. [Crossref]

75. Krone CL, Trzcinski K, Zborowski T, Sanders EA, Bogaert D (2013) Impaired innate mucosal immunity in aged mice permits prolonged Streptococcus pneumoniae colonization. Infect Immun 81: 4615-4625. [Crossref]

76. Martelli S, Pender SL, Larbi A (2016) Compartmentalization of immunosenescence: a deeper look at the mucosa. Biogerontology 17: 159-176. [Crossref] 
77. Wang H, Kotler DP (2014) HIV enteropathy and aging: gastrointestinal immunity, mucosal epithelial barrier, and microbial translocation. Current opinion in HIV and AIDS 9: 309-316.

78. Sato S, Kiyono H, Fujihashi K (2015) Mucosal Immunosenescence in the Gastrointestinal Tract: A Mini-Review. Gerontology 61: 336-342. [Crossref]

79. Biagi E, Nylund L, Candela M, Ostan R, Bucci L, et al. (2010) Through ageing, and beyond: gut microbiota and inflammatory status in seniors and centenarians. PLoS One 5: e10667. [Crossref]

80. Claesson MJ, Jeffery IB, Conde S, Power SE, O'Connor EM, et al. (2012) Gut microbiota composition correlates with diet and health in the elderly. Nature 488: 178184. [Crossref]

81. Erkosar B, Leulier F (2014) Transient adult microbiota, gut homeostasis and longevity: novel insights from the Drosophila model. FEBS Lett 588: 4250-4257. [Crossref]

82. Lakshminarayanan B, Stanton C, O'Toole PW, Ross RP (2014) Compositional dynamics of the human intestinal microbiota with aging: implications for health. J Nutr Health Aging 18: 773-786. [Crossref]

83. O'Toole PW, Jeffery IB (2015) Gut microbiota and aging. Science 350: 1214-1215. [Crossref]

84. Lynch DB, Jeffery IB, Cusack S, O’Connor EM, O’Toole PW (2015) Diet-microbiotahealth interactions in older subjects: implications for healthy aging. Interdiscip Top Gerontol 40: 141-154. [Crossref]

85. Ursell LK, Haiser HJ, Van Treuren W, Garg N, Reddivari L, et al. (2014) The intestinal metabolome: an intersection between microbiota and host. Gastroenterology 146: 1470-1476. [Crossref]

86. Zapata HJ, Quagliarello VJ (2015) The microbiota and microbiome in aging: potential implications in health and age-related diseases. J Am Geriatr Soc 63: 776-781. [Crossref]

87. Kawanishi H (1993) Recent progress in senescence-associated gut mucosal immunity. Digestive diseases 11: 157-172.

88. Guyonnet S, Rolland Y (2015) Screening for Malnutrition in Older People. Clin Geriatr Med 31: 429-437. [Crossref]

89. Remond D, Shahar DR, Gille D, Pinto P, Kachal J, et al. (2015) Understanding the gastrointestinal tract of the elderly to develop dietary solutions that prevent malnutrition. Oncotarget 6: 13858-13898. [Crossref]

90. Zmora N, Bashiardes S, Levy M, Elinav E (2017) The Role of the Immune System in Metabolic Health and Disease. Cell Metab 25: 506-521. [Crossref]

91. Clements SJ, R Carding S (2016) Diet, the intestinal microbiota, and immune health in aging. Crit Rev Food Sci Nutr 10: 1-11 [Crossref]

92. Thevaranjan N, Puchta A, Schulz C, Naidoo A, Szamosi JC, et al. (2017) Age-Associated Microbial Dysbiosis Promotes Intestinal Permeability, Systemic Inflammation, and Macrophage Dysfunction. Cell Host Microbe 21: 455-466.e4. [Crossref]

93. Vaiserman AM, Koliada AK, Marotta F (2017) Gut microbiota: A player in aging and a target for anti-aging intervention. Ageing Res Rev 35: 36-45. [Crossref]

94. Grabezhev LA, Sevostjanova NN, Kolmakov AN, Konovalov SS, Polyakova VO, et al. (2011) Age-related features of expression of cell renewal factors in the intestinal Peyer's patches. Bulletin of experimental biology and medicine 150: 465-467.

95. Kobayashi A, Donaldson DS, Erridge C, Kanaya T, Williams IR, et al. (2013) The functional maturation of M cells is dramatically reduced in the Peyer's patches of aged mice. Mucosal Immunol 6: 1027-1037. [Crossref]

96. Martinet KZ, Bloquet S, Bourgeois C (2014) Ageing combines CD4 T cell lymphopenia in secondary lymphoid organs and $\mathrm{T}$ cell accumulation in gut associated lymphoid tissue Immun Ageing 11:8. [Crossref]

97. Arranz E, O’Mahony S, Barton JR, Ferguson A (1992) Immunosenescence and mucosal immunity: significant effects of old age on secretory IgA concentrations and intraepithelial lymphocyte counts. Gut 33: 882-886.
98. Mabbott NA, Kobayashi A, Sehgal A, Bradford BM, Pattison M, et al. (2015) Aging and the mucosal immune system in the intestine. Biogerontology 16: 133-145. [Crossref]

99. Alok A, Singh ID, Singh S, Kishore M, Jha PC, et al. (2017) Probiotics: A New Era of Biotherapy. Adv Biomed Res 6: 31. [Crossref]

100. Hill C, Guarner F, Reid G, Gibson GR, Merenstein DJ, et al. (2014) Expert consensus document. The International Scientific Association for Probiotics and Prebiotics consensus statement on the scope and appropriate use of the term probiotic. Nat Rev Gastroenterol Hepatol 11: 506-514. [Crossref]

101. Biagi E, Candela M, Turroni S, Garagnani P, Franceschi C, et al. (2013) Ageing and gut microbes: perspectives for health maintenance and longevity. Pharmacol Res 69: 11-20.

102. Frei R, Akdis M, O'Mahony L (2015) Prebiotics, probiotics, synbiotics, and the immune system: experimental data and clinical evidence. Curr Opin Gastroenterol 31: 153-158. [Crossref]

103. Giorgetti G, Brandimarte G, Fabiocchi F, Ricci S, Flamini P, et al. (2015) Interactions between Innate Immunity, Microbiota, and Probiotics. J Immunol Res 2015: 501361. [Crossref]

104. Duncan SH, Flint HJ (2013) Probiotics and prebiotics and health in ageing populations. Maturitas 75: 44-50. [Crossref]

105. Perez Martinez G, Bauerl C, Collado MC (2014) Understanding gut microbiota in elderly's health will enable intervention through probiotics. Benef Microbes 5: 235 246. [Crossref]

106. Vieira AT, Teixeira MM, Martins FS (2013) The role of probiotics and prebiotics in inducing gut immunity. Front Immunol 4: 445. [Crossref]

107. Yaqoob P (2014) Ageing, immunity and influenza: a role for probiotics? Proc Nutr Soc 73: 309-317. [Crossref]

108. Dong H, Rowland I, Thomas LV, Yaqoob P (2013) Immunomodulatory effects of a probiotic drink containing Lactobacillus casei Shirota in healthy older volunteers. Eur J Nutr 52: 1853-1863. [Crossref]

109. Moro-Garcia MA, Alonso-Arias R, Baltadjieva M, Fernandez Benitez C, Fernandez Barrial MA, et al. (2013) Oral supplementation with Lactobacillus delbrueckii subsp. bulgaricus 8481 enhances systemic immunity in elderly subjects. Age (Dordrecht, Netherlands) 35: 1311-1126.

110. Ouwehand AC, Bergsma N, Parhiala R, Lahtinen S, Gueimonde M, et al. (2008) Bifidobacterium microbiota and parameters of immune function in elderly subjects. FEMS immunology and medical microbiology 53: 18-25.

111. Gill HS, Rutherfurd KJ, Cross ML (2001) Dietary probiotic supplementation enhances natural killer cell activity in the elderly: an investigation of age-related immunological changes. J Clin Immunol 21: 264-271. [Crossref]

112. Gill HS, Rutherfurd KJ, Cross ML, Gopal PK (2001) Enhancement of immunity in the elderly by dietary supplementation with the probiotic Bifidobacterium lactis HN019. Am J Clin Nutr 74: 833-839. [Crossref]

113. Arunachalam K, Gill HS, Chandra RK (2000) Enhancement of natural immune function by dietary consumption of Bifidobacterium lactis (HN019). Eur J Clin Nutr 54: 263-267. [Crossref]

114. Vulevic J, Juric A, Walton GE, Claus SP, Tzortzis G, et al. (2015) Influence of galacto-oligosaccharide mixture (B-GOS) on gut microbiota, immune parameters and metabonomics in elderly persons. Br J Nutr 114: 586-595. [Crossref]

115. Bunout D, Hirsch S, Pía de la Maza M, Muñoz C, Haschke F, et al. (2002) Effects of prebiotics on the immune response to vaccination in the elderly. JPEN J Parenter Enteral Nutr 26: 372-376. [Crossref]

116. Macfarlane S, Cleary S, Bahrami B, Reynolds N, Macfarlane GT (2013) Synbiotic consumption changes the metabolism and composition of the gut microbiota in olde people and modifies inflammatory processes: a randomised, double-blind, placebocontrolled crossover study. Alimentary pharmacology \& therapeutics 38: 804-816.

117. Ouwehand AC, Tiihonen K, Saarinen M, Putaala H, Rautonen N (2009) Influence of a combination of Lactobacillus acidophilus NCFM and lactitol on healthy elderly: intestinal and immune parameters. Br J Nutr 101: 367-375. [Crossref]

Copyright: $\odot 2017$ Ramalho R. This is an open-access article distributed under the terms of the Creative Commons Attribution License, which permits unrestricted use, distribution, and reproduction in any medium, provided the original author and source are credited. 